International Journal of Environment, Agriculture and Biotechnology
Vol-6, Issue-4; Jul-Aug, 2021
J Journal Home Page Available: https://ijeab.com/
Journal DOI: $10.22161 /$ ijeab

Article

Peer-Reviewed Journal

\title{
Fishing Effectiveness of Fixed Lift Nets with Multi Color LED Combinations
}

\author{
Pascawan Lebong, Najamuddin, Assir Marimba
}

Magister Program of Fisheries Science, Faculty of Fisheries and Marine Science, Hasanuddin University, Makassar, Indonesia

Received: 08 Jun 2021; Received in revised form: 16 Jul 2021; Accepted: 25 Jul 2021; Available online: 03 Aug 2021

(C)2021 The Author(s). Published by Infogain Publication. This is an open access article under the CC BY license

(https://creativecommons.org/licenses/by/4.0/).

\begin{abstract}
This study aims to analysis at the composition of fish catches and the fishing effectiveness of fixed lift nets fitted with LED lights of varying color combinations. This research was carried out from May to June 2019, located in the waters of Pangkajene Regency and the Islands. Two fixed lift nets units, 16 white light Emitting Diode (LED) lights and 16 pairs of white blue and yellow combination lights, Global Positioning System (GPS), Stop watch, Digital scale, Digital camera, Logbook, Meter, Current meter, Thermometer, Refractometer, and Lux meter. The research method used in this study is Experimental fishing in fixed lift nets fishing operations using LED lights. Experimental research of white and white combination LED light color (control), and blue, white and yellow LED light color (Treatment) used in 2 fixed lift nets. The fixed lift nets used is 15 meters long and 15 meters wide with a height of 25 meters from the seabed to the top pole with a building height of 10 meters above sea level. The data collection technique was carried out by following directly the catching operation of two fixed lift nets with different color combinations of lights. The data collected is the position of the fishing ground and catch data. Data analysis was carried out qualitatively and quantitatively. Qualitative analysis by looking at the technical aspects of operations on the fixed lift nets and data tabulation. Quantitative analysis was carried out using statistical methods and comparison of fish catches using two treatments using LED light colors. The results show that the composition of fish catches using color combinations (white, blue and yellow) shows higher yields when compared to white. The composition of the catch in the fixed lift nets is divided into three groups, namely the main catch (main catch), bycatch (bycatch) and discarded catch (discard). The use of a combination of LED lights on the fixed lift nets got a catch of 1,347.21 Kg, while the use of white LED lights got a catch of 906.21 $\mathrm{Kg}$. The difference between the catches of the two treatments was $441 \mathrm{~kg}$ or $49 \%$ of the fish caught using white LEDs. From these results it can be concluded that the use of color combinations of LED lights is more effective than the use of white LED lights.
\end{abstract}

Keywords - fixed lift nets, use of LED lights, experimental fishing, fishing effectiveness.

\section{INTRODUCTION}

The development of the current fishing business in Indonesia can be said to be increasing rapidly, in (Baskoro et. al. 2011) revealed that one of the rapidly increasing developments is in fishing technology using light, fishing technology using a lot of light in Indonesia itself is widely used. in lift net and purse seine fisheries.

In the eastern region of Indonesia, in general, one of the fishing gears that is widely used by fishermen is the lift nets.
Lift nets fishing gear is a fishing tool that uses light as a lure to attract fish so they can gather in a place or area from a fixed lift nets for easy catching, generally using light tools on the fixed lift nets is used to catch pelagic fish.

In the classification, the fishing gear is grouped in the category of lifting nets. The main part of the lift nets fishing gear is made of bamboo and has a net that can be raised and lowered during the fishing process. This fishing gear that collects small pelagic fish is a fishing gear that utilizes the positive phototactic properties of fish (BBPPI 2007). 
Currently, the development of fixed lift net fisheries by utilizing lights in fishing activities in coastal areas is increasing, it can be seen from the number of fishermen who use this fishing gear. The interest of fishermen in the use of light aids on the fixed lift nets is due to several advantages, namely, (Sudirman and Nessa, 2011): (1) It is technically easy to do (especially fixed lift nets), (2) The investment is affordable by the community, (3) It is a community fishery that has been used by people in coastal areas and around small islands for generations. (3) The catch is always there even though sometimes the amount is small, (4) It absorbs a lot of manpower, and (5) The technology is very simple.

Many studies have been carried out and have developed a lot as in the research conducted by Nadir, 2000, Sudirman et. al. 2001 and 2003. These studies have reached the use of electric light technology, especially the use of mercury lamps.

The use of light aids as a developing technology is generally still very simple. Various efforts to increase the use of light technology, especially in fixed lift nets, have been carried out by many researchers. Among them are the use of 4, 6 and 8 lamp units, the use of petromax lamps which are associated with strong light illumination does not show a significant difference (Herutomo, 1995). In Efendy's (1998) research, there was an effect of increasing catches for each additional number of units on the lift nets operated in the waters of Teluk Awur Jepara, Central Java, but there was no difference between the use of 4 and 5 lamp units, and several studies suggested that there is a difference in the composition of the dominant fish catch for each number of lights used, the use of 2 lamp units produces a dominant catch, namely rebon shrimp, 3 lamp units produce a dominant catch of anchovies, 4 lamp units produce a dominant catch of tembang fish and 5 lamp units produce a dominant catch of layur fish

Improvements in the use of light technology in fixed lift nets have been carried out as well as further studies conducted by Sudirman et.al 2010 regarding the selectivity performance of fixed lift nets carried out in the Makassar Strait, an environmental friendly research on fixed lift nets fishing gear. And followed by further research that examines the use of several types of lights used in fixed lift nets gear, namely (fluorescent, mercury, and incandescent lamps), in this study it was stated that the most effective lamp in relation to attracting the attention of fish was the use of fluorescent lamps in fixed lifts. net (Sudirman et.al 2013). Science and technology that continues to develop at this time may be an improvement in the use of appropriate technology for sustainable fisheries, especially in fixed lift nets fisheries, which in existing studies and those that have been applied by fishermen should need further development.

\section{RESEARCH METHOD}

This research was carried out from May - June 2019, located in the waters of Pangkajene Regency and the Archipelago, with the coordinates of the fishing base 04 ${ }^{\circ} 50^{\prime} 55.7^{\prime \prime}$ South Latitude - 119 $30^{\prime} 56.4^{\prime \prime}$ East Longitude and fishing ground $04^{\circ} 48^{\prime} 21.5^{\prime \prime}$ South Latitude - $119^{\circ}$ $27^{\prime} 056$ and $04^{\circ} 49^{\prime} 22.5^{\prime \prime}$ South Latitude - $119^{\circ} 27^{\prime} 10.5^{\circ}$. Around the fishing ground there are two islands, namely Bangko Island - Bankoang and Kulambing Island, where these two islands are all inhabited as can be seen in Figure 1.

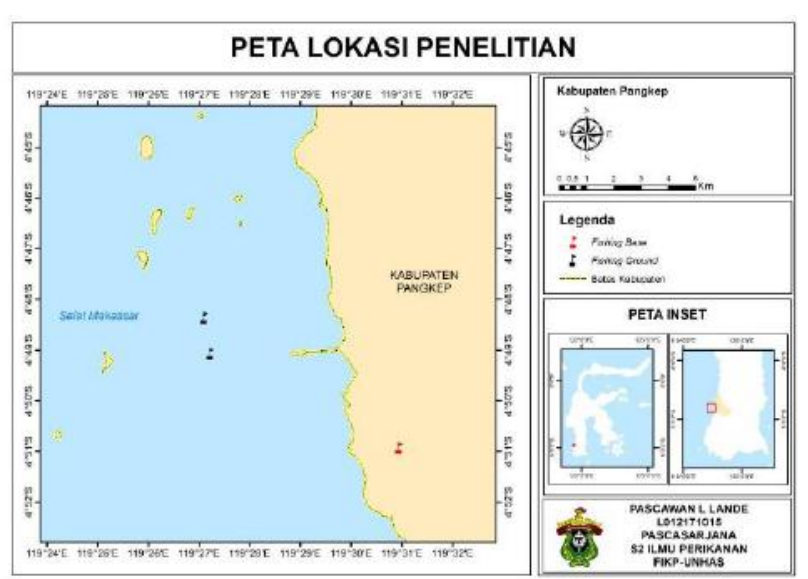

Fig.1: Research site

The tools and materials used in this study are instruments that support the retrieval of research data. The tools and materials used and their uses can be seen in Table 1 .

Table 1. The tools and materials

\begin{tabular}{cll}
\hline No & \multicolumn{1}{c}{ Tool } & Function \\
\hline 1 & Two fixed lift nets & Fish catching \\
& & tool
\end{tabular}

216 white LEDs and 16 white, Fishing aids blue, and yellow combination LEDs

3 Global Positioning System (GPS)

Determining the position of the fishing base, fishing ground and the movement of the handline fishing fleet

4 Stop watch

Calculating the effective time of the hand line fishing process 
5 Digital scale

6 Digital camera

$7 \quad$ Logbook

8 Ruler

9 Current meter

10 Thermometer

11 Refractometer

12 Lux meter
Measuring the weight of the caught fish

Documenting research

Record production and fishing area data

Measuring the length per fish

Measuring current speed

Measuring seawater temperature

Measuring salinity

Measuring light intensity

The research method used in this study is Experimental fishing in fixed lift net fishing operations using LED lights. Experimental research of white and white combination LED light color (control), and blue, white and yellow LED light color (Treatment) used in 2 fixed lift nets. The fixed lift net used is 15 meters long and 15 meters wide with a height of 25 meters from the seabed to the top pole with a building height of 10 meters above sea level. The control net lift is installed with 15 white LED lights with a total power of 376 watts white. And the test lift net installed a combination of LED colors with a total power of 376 watts of different color combinations, 4 units of white LED lights with a power of 27 watts, 6 units of blue lights with a power of 27 Watts, and Yellow Lights with a power of 40 watts consisting of of 2 units, the 13 watt Yellow light consists of 2 units. Illustration of the use of Neon and LED lamps used in research. The data collected are catch production and oceanographic data on two fixed lift nets with different color combinations of LED lights.

\section{Data Collection Technique}

The data collection technique was carried out by following directly the capture operation of two fixed lift nets with different color combinations of lights. The data collected are as follows:

\section{Position of the fishing ground}

The position of the fishing area is taken using a GPS (Global positioning system) at each fishing group. Data collection on the position of the fishing ground is done to determine the location of the fixed lift net.

\section{Catch data}

Counting the number of catches on two fixed lift nets with different color combinations of LED lights. This is done to determine the number and composition of catches in two color combinations of LED lights.

\section{Data Analysis}

Data analysis was carried out qualitatively and quantitatively. Qualitative analysis by looking at the technical aspects of operations on the fixed lift net and data tabulation. Quantitative analysis was carried out using statistical methods and comparison of fish catches using two treatments using LED light colors.

\section{RESULTS AND DISCUSSION}

\section{Composition of Catches}

Catches on fixed lift nets that use a combination of LEDs include anchovies (Stolephorus indicus), lemuru (Sardinela fimbriata), peperek (Leiognathus equulus), bilis (Herklotsichthys dispilonotus), kwee (Carangoides dinema), peperek (Leiognathus equulus), squid - squid (Loligo sp), selar (Anodontosoma chacunda), selar kuning (Selaroides leptolepis), selar tengkek (Megalaspis cordyla), and tembang. based on the proportion caught sequentially such as pestle (Sphyraena forsteri), machete (Chirocentrus dorab), jackfruit seed (Upeneus sulphureus), mackerel (Scomberomorus commerson), lencam (Lethrinus lentjan), layur (Trichiurus sp. B), small crab (Portunus pelagicus), gerot-gerot (Pomadasys andamanensis), and balombong (Atherinomorus egibyl), bitter gourd (Arothron manilensis), pufferhead (Lagocephalus sceleratus), stone puffer (Torquigener brevipinnis), chickens (Paramonacanthus), crocodile tong (Syngnathoides biaculeatus), bluncat (Arcygobius baliurus).

Based on the results of the study, the composition of fish catches using a combination of colors (white, blue and yellow) showed higher yields when compared to white. The composition of the catch in the fixed lift net is divided into three groups, namely the main catch (main catch), bycatch (bycatch) and discarded catch (discard). The main catch (main catch) on fixed lift neta that uses LEDs is $1,105 \mathrm{~kg}$ on a fixed lift net with white LEDs as much as 722.49 , by catch on fixed lift neta that uses LED color combinations as much as $202.24 \mathrm{~kg}$ and on fixed White LED lift net is $153.69 \mathrm{Kg}$, Discarded catch is $39.47 \mathrm{Kg}$ LED color combination on White LED is $30.03 \mathrm{Kg}$. By-catch is a catch of fish that consists of three types of catch, while discarded catch is a catch that has no economic value or the economic value of the fish is classified as very low, so the fish caught are 
usually discarded by fishermen. The limited space for fish storage is also a factor in the fish being discarded. To see the composition of the catch can be seen in Figure below.

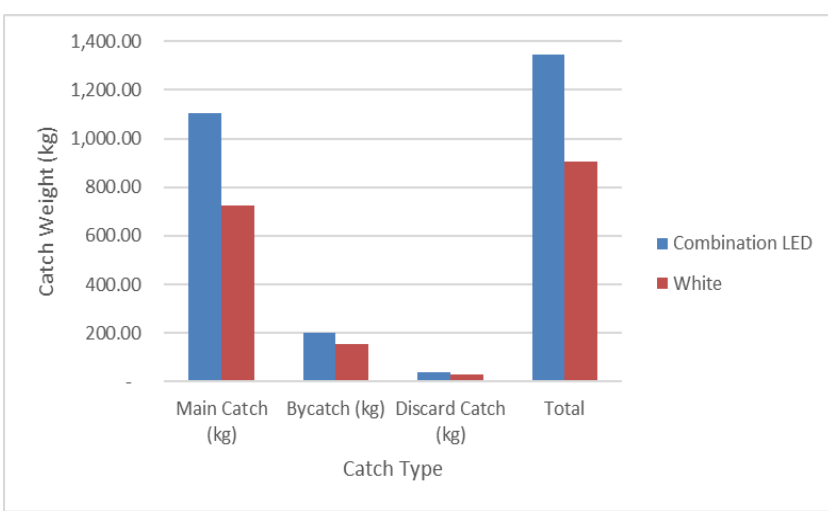

Fig 2: Composition of fish catches using a combination of LED light colors

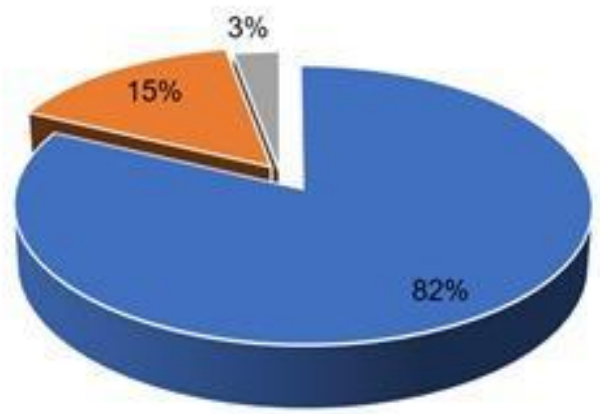

(a)

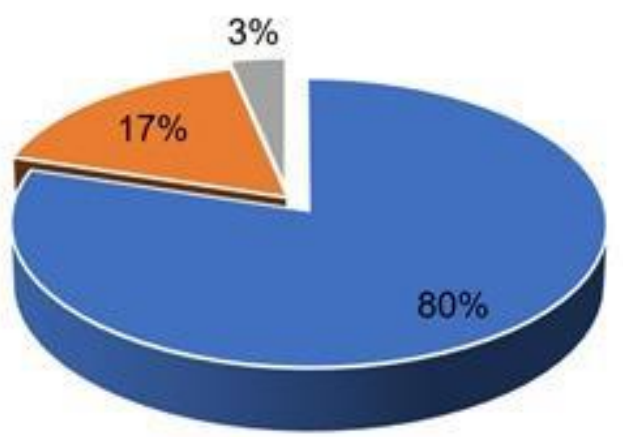

(b)

Discard $(\mathrm{kg})$

Main Catch $(\mathrm{kg})$

Bycatch (kg)

Fig.3: (a) Catch composition using combination color LED (b) catch composition using white LED
The total main catch on the fixed lift net using the LED color combination is more than the percentage of the main catch in the fixed lift net using the White LED. With a total percentage of $82 \%$ and on the white LED by $80 \%$. Judging from the bycatch, the percentage of the total catch is greater in lift nets that use White LEDs by $17 \%$ and in fixed lift nets with LED color combinations by $15 \%$. Meanwhile, the percentage of catches and discharges between the two lift nets is the same as the total percentage of $3 \%$.

\section{The Effectiveness of Using a Combination of LED Lights}

The use of assistive devices in the form of lights is now widely used by fishermen, especially for fixed lift net fishermen in Pangkep Regency. Based on the results of the study, it was reported that it showed that electric lights were effective in attracting the attention of fish around the lift net (Ta'ladin, 2000). In this study, the lamp used is a type of Light Emitting Diode (LED). The effectiveness of catching fish using fixed lift net fishing gear in Pangkep Regency can be seen from the catch produced with two combination treatments of LED and white lights. In the previous discussion, it has been explained that there are significant differences in catches. The use of a combination of LED lights on the fixed lift net got a catch of $1,347.21 \mathrm{Kg}$, while the use of white LED lights got a catch of $906.21 \mathrm{Kg}$. The difference between the catches of the two treatments was $441 \mathrm{~kg}$ or $49 \%$ of the fish caught using white LEDs. From these results it can be concluded that the use of color combinations of LED lights is more effective than the use of white LED lights.

Differences in catches on fixed lift nets that use color combinations, namely the blue color which is suspected to be supporting the number of catches on the step-by-step fixed lift nets that uses color combinations, blue lights have a low wavelength so that their penetrating power in waters is very deep research conducted by Amos, CT (2019) which states that blue light has a low wavelength so that its range is very far in the water. This light is able to attract small pelagic fish and demersal fish. This allows greater opportunities for fish at more distant locations to respond to light to attract and congregate in the catchable area of the fixed lift nets.

In addition, Aliyubi FK et al. (2015) said that the use of light colors on fixed lift nets will certainly affect the fish caught. The theory from several previous studies shows that white and red lights do not provide maximum results compared to other light colors such as blue and yellow.

The next question is whether the use of white LED lights has been effective?. The use of white LED lights is still effective with the catch obtained by $906.21 \mathrm{Kg}$ consisting of the main catch of $722.49 \mathrm{Kg}$, by-catch of $153.69 \mathrm{Kg}$ and Discard of $30.03 \mathrm{Kg}$. The use of a combination of LED 
lights (White - Blue - Yellow) is more effective in catching fish when compared to the use of white LED lights, this study supports the results of previous studies that specifically examined fixed lift nets that use LEDs, one of which is the use of white LEDs compared with CFL Lamps conducted by Susanto, A (2017). From this study concluded that commercial LED light distribution can penetrate wider and deeper into the catchment area than CFL lamps and is good enough to attract target species of anchovy. The use of LED lights significantly affects the catch of anchovy and saves fuel consumption. LED lamps are a potential light source that is suitable to replace CFL lamps in developing fisheries, in other words the use of LEDs is very good compared to other types of lamps. Through this research, it can be seen that the modification of fixed lift nets using a combination of LED colors is proven to increase fish catches seen from the effectiveness of the fixed lift nets studied.

This study is also in accordance with several previous studies that examined differences in catches on fixed lift nets with different LED colors. Sudirman (2003) said that the color of the light greatly affects the total weight of the fish caught. From the results of research by Gustaman (2012), the use of blue lights has an effect on the catch of some demersal fish. Furthermore, Gustaman said that the distribution of demersal fish such as petek is also the most caught in the use of blue light because the light has a strong penetrating power in the waters. This indicates that the total catch on fixed lift nets with LED color combinations can be caused by the use of blue LED lights in combination to reach fish in deeper waters and collect fish to the fixed lift nets catch area.

\section{CONCLUSION}

The composition of fish catches using color combinations (white, blue and yellow) shows higher yields when compared to white. The composition of the catch in the fixed lift nets is divided into three groups, namely the main catch (main catch), bycatch (bycatch) and discarded catch (discard). The use of a combination of LED lights on the fixed lift nets got a catch of $1,347.21 \mathrm{Kg}$, while the use of white LED lights got a catch of $906.21 \mathrm{Kg}$. The difference between the catches of the two treatments was $441 \mathrm{~kg}$ or $49 \%$ of the fish caught using white LEDs. From these results it can be concluded that the use of color combinations of LED lights is more effective than the use of white LED lights.

\section{REFERENCES}

[1] Aliyubi FK, Boesono H, Setiyanto I. 2015. Perbedaan Hasil Tangkapan Berdasarkan Warna Lampu Pada Alat Tangkap Bagan Apung Dan Bagan Tancap Di Perairan Muncar Kabupaten Banyuwangi. Journal of Fisheries Resources Utilization Management and Technology. 4(2):93-101.

[2] Baskoro, S.M., A.A. Taurusman, and Sudirman. 2011. Tingkah Laku Ikan Hubungannya Dengan Ilmu Dan Teknologi Perikanan Tangkap. Lubuk Agung. Bandung. p 258.

[3] Christianti T. Amos, Revols D.Ch. Pamikiran Dan Patrice N. I. Kalangi. 2019. Pengaruh Warna Lampu Light Emitting Diode Dalam Air Terhadap Hasil Tangkapan Ikan Teri (Stolephorus Commersonii) Dengan Bagan. Jurnal Ilmu dan Teknologi Perikanan Tangkap 4(2): 45-51.

[4] Gustaman G, Fauziyah and Isnaini. 2012. Maspari Journal 4 (2) 92-102

[5] Sudirman dan M. N. Nessa. 2011. Perikanan Bagan dan Aspek Pengelolaannya. Penerbit Universitas Muhammadiyah Malang. p 234.

[6] Sudirman., M.S. Baskoro, Zulkarnain, S. Akiyama \& T. Arimoto., 2001b. Light Adaptation Process of Jack Mackerel (Trachurus japonicus) by different Light Intensities and Water Temperatures. Proceeding of the JSPS International Symposium Fisheries Sciences in Tropical Area; Bogor- Indonesia Agt, 21-25, 2000. Sustainable Fisheries in Asia in The New Millennium. Published by TUF International JSPS Project. .10. p 205-208.

[7] Sudirman. 2003. Analisis Tingkah Laku Ikan Untuk Mewujudkan Teknologi Ramah Lingkungan Dalam Proses Penangkapan Pada Bagan Rambo di Selat Makassar. Disertasi. Pascasarjana IPB. p 307.

[8] Susanto, A. 2017. Fishing Efficiency Of LED Lamp For Fix Lift Net Fisheries In Banten Bay Indonesia. Turkish Journal of Fisheries and Aquatic Sciences 17: 283-291.

[9] Herutomo, A.N., 1995. Pengaruh Intensitas dan Warna Cahaya Terhadap hasil Tangkapan Cumi - Cumi (Loligo sp) Pada Perikanan Bagan Tancap di Perairan Suradadi, Kabupaten Tegal. Skripsi Program Studi Pemanfaatan Sumberdaya Perikanan Fakultas Perikanan Institut Pertanian Bogor. p. 58.

[10] Efendy, M. 1998. Pengaruh Jumlah Lampu Terhadap Komposisi dan Hasil Tangkapan Bagan Tancap di Perairan Teluk Awur, Jepara Jawa Tengah. Skripsi Program Studi Pemanfaatan Sumberdaya Perikanan Fakultas Perikanan Institut Pertanian Bogor. p. 43. 